\title{
Vibration Estimation of Spiral Bevel Gears by Monitoring the Exterior Vibration
}

$\begin{array}{llll}\text { 正 } & \text { 青山 } & \text { 栄一 } & \text { (同志社大) } \\ \text { 正 } & \text { 上西 } & \text { 康弘 } & \text { (三菱自・I) } \\ \bigcirc & \text { 中田 } & \text { 康弘 } & \text { (同志社大・院生) }\end{array}$

Eiichi AOYAMA, Faculty of Engineering, Doshisha University Yasuhiro UENISHI, Mitsubishi Motors Corporation Takeshi YAMADA, Ishida Corporation Yasuhiro NAKATA, Graduate Student, Doshisha University

Key Words: Gear, Spiral Bevel Gear, Vibration, Rotational Vibration, Transfer Function, Monitor, Meshing Transmission Error

\section{1. 緒言}

かさ歯車は，互いに交わる軸の動力伝達に用いられる重 要な機械要素の一つである．かみ合い時の歯車自身の回転 方向挙動を評価する方法として，平歯車，はすば歯車は回 転方向振動が計測されている(1-3)。しかしながら，歯車の 回転方向振動を測定するにあたって，ハウジング内部の柬 車に逐一測定器をつけて測定するのは, 生産管理, コスト 面から実用的ではない.

一方，本研究室の以前の研究によりまがりばかさ歯車に ついても歯車の回転方向振動がハウジング内部の振動に大 きく影響を与えていることと明らかにしている(4)，そこで 本研究では, ハウジング内部の歯車の回転方向振動を, 測定容易なハウジング外部のフランジの回転方向振 動でモニタリングする手法を検討した．まず，フラン ジの回転方向振動により歯車の回転方向振動を評価 する事を目的とし，ハウジング内部の被動歯車と外部 のフランジに加速度ピックアップを取り付けた.そし て振動源である歯車の回転方向振動を直接測定する と同時に,外部のフランジ部の回転方向振動を測定し， その振動挙動を比較し,フランジ部でのモニターの有 効性を示した。 また，歯車の振動加速度とフランジの 振動加速度の間の伝達関数を用いる事で, 本手法の妥 当性を示すと共に，適用範囲についても検討した。

\section{2. 実験方法}

本研究の対象にしたまがりばかさ齔車は，エリコン式等 高歯まがりばかさ歯車である。そして，実駆動時にかみ合 う歯車の挙動を調べるために，加速度ピックアップを駆動 側，被駆動側にそれぞれ 2 個 $180^{\circ}$ 対向する位置に回転方 向に対して同方向に取り付け，回転方向振動を測定した. また，フランジ部の回転方向振動の測定も同様に行った。

次にハンマリング実験を行い，駆動状䅧を想定し，負荷 をかけた状態でフランジの取り付けねじ部にアームを付け， 回転方向に打慗を与えた。

\section{3. 実験結果および考察}

3.1 かみ合い伝達誤差と被動歯車

駆動歯車と被動歯車は相対運動をしており，各歯車の運 動は理論上，各慣性質量の逆数に比例するものと考えられ
る.そこで, 歯車振動を測定する場合には駆動側, 被動側ど ちらか一方の振動を測定すればその歯車対の振動をある程 度把握することができると考えられる，そこでまず，被動 歯車だけの测定で十分な精度が得られるかを検討する伛め に, 被動歯車の加速度ピックアップによる振動加速度の測 定結果とかみ合い伝達誤差の関係の図をFig. 1 に示す。図 より，加速度の測定値とかみ合い伝達融差は直線関係にあ り, 被動歯車の振動加速度だけである程度の評価が可能で あることがわかる。

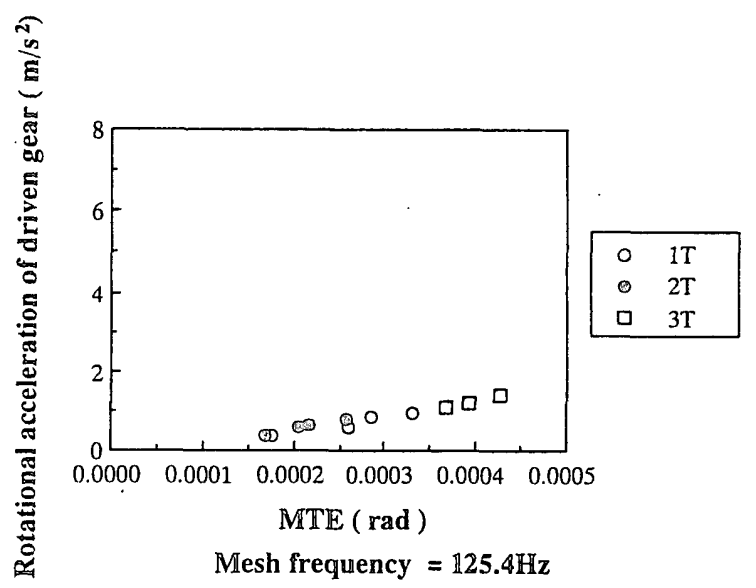

Fig.1 Relation between rotational scceleration of driven gears and meshing iransmission error

(Torque $=4.68,14.0,23.4,46.8 \mathrm{Nm}$ )

\section{2 被動歯車回転挙動とフランジ部回転挙動}

次に駆動時における被動菌車回転方向振動とフランジ部 回転方向振動の関係を Fig. 2 に示す.二つの間にはおおむ ね比例関係が有ることがわかる.ここで，Fig. 2 における 直線の傾きは被動歯車とフランジ部のかみ合い周波数にお ける伝達関数となる.Fig. 3 は負荷トルクを変更した場合 の直線の傾きを示します.Fig. 3 より負荷トルクの影響が 少ない事がわかる。これより，フランジ部の回転方向振動 を測定することにより，被動歯車の回転方向振動を予測す ることが可能であると考えられる。

日本機械学会東海支部第49期総会講演会講演論文集（'00．3．10-11）No.003-1 


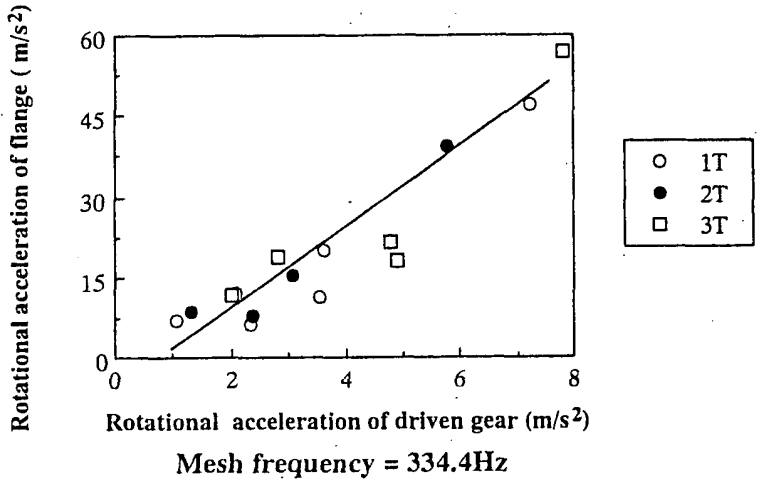

Fig.2 Relation between rotational acceleration of driven gears and of flange

(Normal rotation,

torque $=4.68,14.0,23.4,46.8 \mathrm{Nm})$

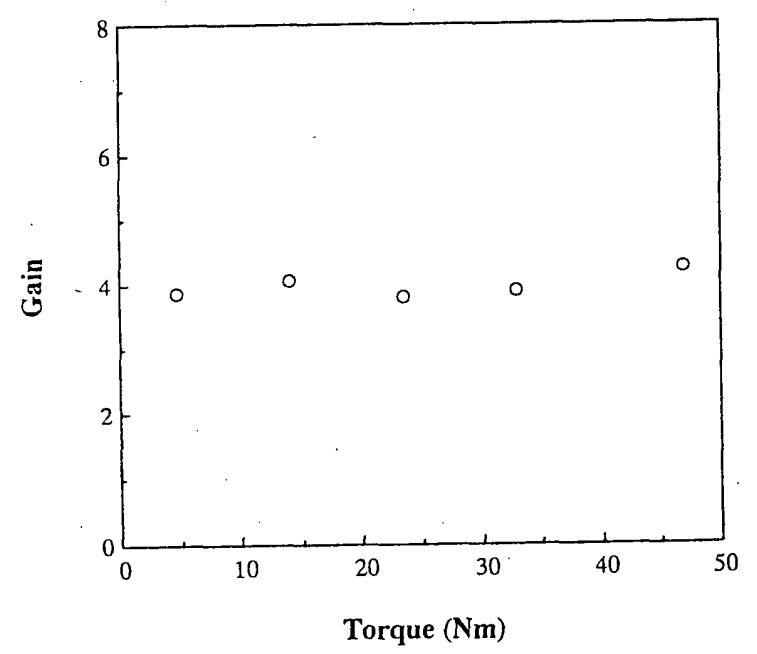

Fig.3 Relation between torque and gain (Normal rotation)

\section{3 ハンマリング実験}

実駆動時の実験結果のみで振動源である歯車の回転方向 振動を推定するには必要とするデータ数が多いため,より 簡便な方法で歯車の回転方向振動を評価できることが望ま しい.

そこで歯車を回転させない状態でハンマリング実験の結 果により被動歯車回転方向振動とフランジ部回転方向振動 の間の伝達関数を求め, これに駆動して得られるフランジ 部回転方向振動のパワースペクトルを積することにより被 動菌車回転方向振動を推定した. 被動歯車回転方向振動の 実験結果に対する伝達関数を用いた計算結果の比較を Fig. 4 に示す.Fig. 4 より, かみ合い 1 次周波数の振動加速 度レベルが実験, 計算結果ともほぼ同様の值を示している ことがわかる.したがって，フランジ部回転方向振動によ って被動歯車回転方向振動レベルを推定できることが確認 された.

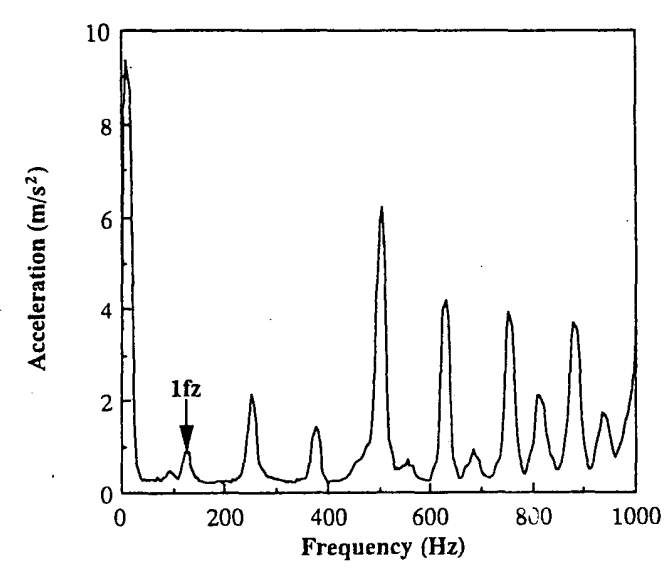

(a) In opration

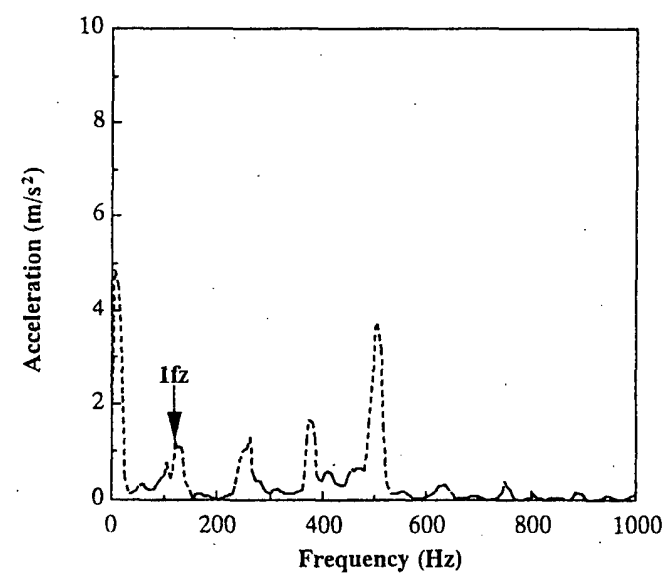

(b) Calculating

Fig.4 Comparision between experimental data and calculated results

(Tooth bearing : 3T, mesh frequency $=125.4 \mathrm{~Hz}$ torque $=\mathbf{2 . 3 7 5} \mathrm{Nm}$ )

4. 結言

（1）歯車軸上に配㯰されたフランジ部の回転方向振動を測 定することによって被動歯車の回転挙動を推定するこ とができる。

（2）フランジ部と歯車間の伝達関数を評価することにより， 本手法の有効な範囲を明らかにできることがわかっ た.

\section{参考文献}

1. 寺内, 永村, 専徳, 上谷, 機論, $52-479, C(1986)$, 1985-1991

2. 梅澤，鈴木，佐藤，機論， 51-469，C (1985)，2316-2322

3. 前沢, 田中, 能上, 中村, 松永, 機論, 52-480, C (1986), 2113-2119

4. 廣垣, 青山, 上西, 橋本, 新田, 新井, 機論, 62-597, C (1996)， 1998-2004 